Adyani, L., Suzanna, E., Safuwan, S., \& Muryali, M. (2019). Perceived Social Support And Psychological Well-Being Among Interstate Students At Malikussaleh University. Indigenous: Jurnal Ilmiah Psikologi, 3(2). 98-104 doi:https://doi.org/10.23917/indigenous.v3i2.6591

\title{
Perceived Social Support And Psychological Well-Being Among Interstate Students At Malikussaleh University
}

\author{
Liza Adyani ${ }^{1}$ Ella Suzanna ${ }^{2}$ Safuwan ${ }^{3}$ Muryali $^{4}$ \\ Medical Faculty, Psychology Department, Malikussaleh University ${ }^{123}$ \\ Social and Political Science Faculty, Malikussaleh Universiy ${ }^{4}$ \\ lizaadyani@gmail.com ${ }^{1}$
}

\begin{abstract}
This study aims to examine the relationship between perceived social support and psychological well-being among interstate students at Malikussaleh University, Lhokseumawe. It is hypothesized that there will be positive relationship between perceived social support and psychological well-being. As the second largest state university in Aceh, students at Malikussaleh University come from different parts of Aceh and Indonesia. Thus, it is important to understand their psychological well-being as it will help them to be more satisfied and happy while being away home. A number of 105 interstate students were participated in this study by answering a set of questionnaire. The questionnaire was provided online by using google docs platform. To obtain deeper meaning of their experiences, 10 students were selected to join focus group discussion (FGD). The collected data were analyzed by using correlation Pearson product moment. The result showed that there wasa positive correlation between perceived social support and psychological well-being with $r=0.40$ and $p=0.000$ ( $p<0.05$ ). Additional findings from FGD are also included in discussion section.
\end{abstract}

Keywords: Interstate Students, Perceived Social Support, Psychological Well-Being

Abstraksi. Penelitian ini bertujuan untuk melihat hubungan antara dukungan sosial (perceived social support) dan psychological well-being pada mahasiswa rantau di Universitas Malikussaleh, Lhokseumawe. Hipotesis penelitian ini adalah adanya korelasi positif antara kedua variabel. Sebagai universitas negeri kedua terbesar di Aceh, mahasiswa universitas Malikussaleh datang dari berbagai wilayah di Aceh dan Indonesia. Oleh karenanya, penting untuk memahami psychological well-being mereka karena itu bisa membuat mereka lebih puas dan bahagia selama berada jauh dari rumahnya. Sebanyak 105 mahasiswa rantau berpartisipasi dalam penelitian ini dengan menjawab kuesioner penelitian. Kuesioner dibuat dalam bentuk link online dengan menggunkan google docs. Untuk memahami pengalaman mereka lebih mendalam, 10 siswa dipilih untuk mengikuti sesi Focus Group Disucssion (FGD). Data analisis dilakukan dengan menggunakan teknik korelasi Pearson. Hasil penelitian menunjukkan adanya korelasi positif antara dukungan sosial dan psychological well-being dengan $r=0.40$ dan $p=0.000(p<0.05)$. Temuan tambahan dari FGD akan dibahas di bagian pembahasan.

Kata kunci: Mahasiswa Rantau, Dukungan Sosial, Psychological Well-Being

\section{INTRODUCTION}

Psychological well-being is an important aspect in one's life as it is refers to positive mental health (Edward, 2005). Psychological well-being is often defined as some combination of positive affective states such as happiness and functioning with optimal effectiveness in 
individual and social life (Deci \& Ryan 2008). According to Huppert (2009) psychological well-being is the state that someone's life going well and is functioning effectively. Research also suggested that positive psychological well-being were associated with positive life qualities. People with high subjective well-being are described as being happy, capable, well-supported, and satisfied with life (Winefield, Gill, Taylor, \& Pilkington, 2012).

Studies supported that interstate students experience stressful moment in adjusting to the new place. Interstate students are facing many changes in their life (Rufaida \& Kustanti, 2017). Rufaida and Kustanti (2017) called this situation as 'culture shock' where the students were involved in re-adjustment in solving new challenges including lecturers, peers, academic pressure, personal relationship, etc. This adjustment is an important factor to create student's mental health (Desmita, 2009).

According to Dollete, Steese, Phillips and Matthews (2004) social support is an important aspect that is needed to be reviewed as it can be a buffer against life stressors as well as help in promoting health and wellness. Perceived social support is subjective evaluation of resources received in a given situation and its felt appropriateness and satisfaction (Vaux 1990). It is the experience of being valued, respected, cared about, and loved by others who are present in one's life (Gurung, 2006).

Students who perceived themselves as not being accepted in a new place tend to be lower in self-esteem, not satisfied, perceived discrimination, and withdrawal from social activities (Awang, Kutty, \& Ahmad, 2014). These conditions may lead to lower psychologial well-being.

Research on social relationships and health indicated that social support is associated with general well-being (Ryan \& Willits, 2007; Thomas, 2009). According to Awang, Kutty and Ahmad (2014), student well-being has diverse dimensions including academic attainment, happiness and enjoyment, ability to adapt with the campus life, and social life in and out of university compound.

Based on the above description, it is believed that social support will have a positive relationship with psychological well-being. The present study aims to investigate the relationship when it applies to interstate students. Thus the hypothesis postulate to the present study are:

H0: There will be no association between perceived social support and psychological well-being among interstate students at Malikussaleh University

H1: There will be a positive relationship between perceived support and psychological well-being among interstate students at Malikussaleh University, in which students who score high in perceived social support will have better psychological well-being.

\section{METHOD}

This study employed cross-sectional method where participants answered to a set of questionnaire to measure perceived social support and psychological well-being at only one point of time. The design was selected because this study design was efficient in terms of cost, completion time, and questionnaire administration (Paulhus \& Vazire, 2007).

The main variables of the study were perceived social support, psychological wellbeing, and interstate students. Perceived social support refers to "transpiring from multiple sources (parents, teachers, close friends, classmates, and school) and consisting of multiple types (emotional, informational, appraisal, and instrumental), which may serve to improve a student's adjustment and outcomes" (Demaray, 2005). Psychological well-being, expresses the level of optimal and healthy functioning (Ryff, 1989).

Interstate students in this study refers to active students at Malikussaleh University who are not from North Aceh, East Aceh, Bireun, Sigli, and Pidie Jaya. The reason for not choosing students come from this areas 
is because Malikussaleh University is located in Lhokseumawe, while those areas are close to Lhokseumawe and share similar culture. In addition, demographic variables (i.e. age, gender, duration of study, and origin tribe) to describe the condition of participants were also included.

Participants were recruited by using purposive sampling technique. Due to convinience reason, online questionnaire was created by using google docs app. By using this app, participants can also share the link to those who suit the criteria for the study. Thus snowball technique was also employed.

A total of 105 students from various course of study in Malikussaleh University became participants in this study. To ensure the similar sample characteristics and decrease response bias (Paulhus, 1991), these employees also fulfilled three inclusion criteria, which include (1) must be an active student; (2) has been in Aceh for a minimum period of six months; and (3) is not from North Aceh, Lhokseumawe, East Aceh, Bireun, Sigli, or Pidie Jaya.

In the present study, two measures were utilized to assess perceived social support and psychological well-being. To measure perceived social support, we used Multidimensional Scale of Perceived Social Support (MSPSS) that was developed by Zimet, Dahlem, Zimet and Farley (1988). The scale consisted of 12 items, with responses range between 1 (strongly disagree) to 5 (strongly agree), which also included a mid-point (neither disagree nor agree). The total score ranged from 12 to 60 with high scores reflecting a high level of perceived social support while low scores indicating a low level of perceived social support. In the present study, the alpha coefficient for this scale is 0.84 , indicating a good level of internal consistency. Next, Satisfaction with life scale (SWLF) developed by Diener (1985) was used to measure psychological well-being. The measure consisted of five items. Participants rated the items on a five-point Likert-type scale, ranging from 1 (strongly disagree) to 4 (strongly agree). The measure was also found to have good internal consistency with $\alpha=0.74$.

Two steps were carried out to test the study's hypotheses. First, descriptive statistical analysis were conducted to examine the characteristics of the study's variables. These analysis provide information about the participants and the variables so that the data would be easy to be described and interpreted. Second, correlation coefficients were computed through Pearson correlation coefficient to determine the statistical significance of the relationship between perceived social support and psychological wellbeing as proposed by the study's hypothesis. Additionally, Focus Group Discussion (FGD) with 10 students was also conducted as it can provide deeper experience of the students. A Focus Group Discussion is a qualitative research method and data collection technique in which a selected group of people discusses a given topic or issue in-depth, facilitated by a professional, external moderator (Barbour, 2014). Openended interview guidellines was prepared before the FGD carried out. Students were selected randomly from different subject of studies.

\section{RESULT AND DISCUSSION}

All data were checked and analysed using IBM SPSS version 24.0 software. The results of the descriptive analysis revealed that the avarage age for participants was 20 years old and most of the students are at their 5th semester. $67 \%$ participants were female and $33 \%$ were male. The participants, on average, obtained a total score of $45.6(\mathrm{SD}=7.2)$ for perceived social support indicating that the students received high social support, while avarage score for life satisfaction was $16.3(\mathrm{SD}=3.5)$. Most students are from Acehnese tribe with 20 participants (19\%) followed by Bataknese and others (e.g. Banjar, Dayak, Melayu, Arab, Pakpak) shared same number (17.1\%). The details of these results are presented in Table 1 . 
Tabel 1. Demographic Characteristics Of The Sample The Distribution Of The Study Variables

\begin{tabular}{|c|c|c|c|c|}
\hline & $\mathbf{N}(\%)$ & Mean & SD & Range \\
\hline Gender & & & & \\
\hline Male & $35(33 \%)$ & & & \\
\hline Female & $70(67 \%)$ & & & \\
\hline Age (years old) & 105 & 20.18 & 1.29 & 7 \\
\hline $\begin{array}{l}\begin{array}{l}\text { Duration } \\
\text { (semester) }\end{array} \text { of study } \\
\end{array}$ & 105 & 5.18 & 2.37 & 12 \\
\hline Origin Tribe & & & & \\
\hline Aceh & $20(19 \%)$ & & & \\
\hline Jawa & $27(25.7 \%)$ & & & \\
\hline Sunda & $4(3.8 \%)$ & & & \\
\hline Minang & $12(11.4 \%)$ & & & \\
\hline Gayo & $6(5.7 \%)$ & & & \\
\hline Batak & $18(17.1 \%)$ & & & \\
\hline Others & $18(17.1 \%)$ & & & \\
\hline $\begin{array}{l}\text { Perceived Social Support } \\
\text { (PSS) }\end{array}$ & 105 & 45.6 & 7.2 & 37 \\
\hline Life Satisfaction (LS) & 105 & 16.3 & 3.5 & 17 \\
\hline
\end{tabular}

The correlation coefficients among support and psychological well-being are shown demographic characteristics, perceived social in Table 2.

Tabel 2. Correlation between demographic variables, predictor, and outcome variable

\begin{tabular}{|c|c|c|c|c|c|c|}
\hline \multirow{2}{*}{ Variables } & \multicolumn{5}{|c|}{$\mathrm{N}=105$} & \multirow[b]{2}{*}{6} \\
\hline & 1 & 2 & 3 & 4 & 5 & \\
\hline 1. Gender & 1 & $-.23^{*}$ & -.20 & .03 & -.07 & .04 \\
\hline 2. Age & $-.23^{*}$ & 1 & $.824^{* *}$ & .11 & .14 & .13 \\
\hline 3. Duration of study & .19 & $.824^{* *}$ & 1 & .08 & .05 & .09 \\
\hline 4. Origin & .03 & .11 & .08 & 1 & -.17 & .11 \\
\hline 5. PSS & .04 & .14 & .09 & .11 & 1 & $.40^{* *}$ \\
\hline 6. LS & -.07 & .13 & .05 & -.17 & $.40^{* *}$ & 1 \\
\hline
\end{tabular}

Based on the result presented above, it was observed that there was no correlation between demographic variables with predictor and outcome variable. It is also noted that there was no relationship between origin tribe with perceived social support or life satisfaction. This result suggested that cultures did not correlate with psychological well-being,

However, there was a positive correlation between PSS and LS. According to Pallant (2016), correlation ( $r$ ) more than .30 has medium correlation. Thus, hypothesis (H1) for the present study is accepted and $\mathrm{HO}$ is rejected.

This results were supported by previous studies suggested that social support was asscociated with psychological well-being (Awang, Kutty, \& Ahmad, 2014; Gulacti, 2010). Awang, Kutty, and Ahmad (2014) argued that students who perceived social support will have more confidence as they have a good supporting environment. As a result, this assistance from 
peers emerged as strong support for academic, social, and emotional adjustment.

Furthermore, by receiving support, students will perceive their surroundings more friendly and eventually affect their happines (Karademas, 2006). On the other and, lack of social support could be a negative predictor toward minority students (Dennis, Phinney, \& Cuatecco, 2006). Several studies revealed that social support correlate negatively with psychological problems such as stress, depression, and other psychiatric disorders (e.g. Friedlander, Reid, Shupak, \& Cribbie, 2007). The impact of psychological problems could be reduced when the students have good and sufficient social support. This is because by receiving social support students will be able to deal with various stressors in their academic life and facilitate a positive adjustment process (Rawson, Bloomer, \& Kendall, 1994) which will eventually influence their psychological well-being (i.e. life satisfaction).

Additionally, findings from FGD was also supported this result. It was revealed that students with positive view on social support tend to be more satisified and have lower anxiety in term of academic issues as well as relationship issues. Furthermore, students who are mingling with local students or other than their own group involved in more activities and thus received more support. Students also suggested the need of implementation interstate students centre where students can seek help for various issues they are facing. It is also noted that other than friends, interstate students was also received support from lecturers and landlords. Overall, interstate students claimed to be happy to study at Malikussaleh University and experience no discrimination. There were however, other factors that make interstate students at Malikussaleh University feel anxious as Aceh province is perceived vulnarable to disaster (e.g. Tsunami and earthquake) and reappear of Acehnese Freedom Movement (Gerakan Aceh Merdeka).

Therefore, the findings of the present study provided evidence for the relationship between social support and psychological problems among students. The relationship between these two variables was anticipated as the two constructs were found significantly correlated in the previous studies.

\section{CONCLUSION}

The findings of this research contribute in understanding pschological well-being of interstate students. Findings from this study may be useful in assissting educators, counsellors, psychologists, as well as university board members to develop strategies to enhance student psychological well-being. The experience of being interstate students can be both challenging and exciting. As indicated in the current study, social support is an important predictor in interstate students. Students who perceived to have social support are reported to have better psychological well-being. Also, as findings indicated the importance of student centre, it is important for the senior students and lecturers as well as university to help the interstate students to adapt to a new learning environment, and rebuilding 'supportive atmosphere'. Universities should provide more activities that can attract interstate students to be more involved such as culture week where students from different backgrounds can present their cultures.

\section{DISCLAIMER}

A part of this study has been presented (but not published) at Asian Association of Indigenous and Cultural Psychology (AAICP) in Sabah, July 2018.

\section{REFERENCES}

Awang, M.M., Kutty, F.M., \& Ahmad, A.R. (2014). Perceived social support and well being: firstyear student experience in university. International Education Studies. 7 (13), 261-270.

Awang, M. M., Kutty, F.K., \& Ahmad, A.R. (2014). Examining gaps between students' expectations 
and experiences in a private university. Mediterranean Journal of Social Sciences. 5(8), 396401 .

Barbaour, R. (2014). Analyzing Focus Groups.In The SAGE Handbook of Qualitative Data Analysis, ed. Uwe Flick. London: SAGE Publications.

Deci, E. L., \& Ryan, R. M. (2008). Hedonia, eudaimonia, and well-being: An introduction. Journal of Happiness Studies. 9, 1-11.

Demaray, M. K., Malecki, C. K., Davidson, L. M., Hodgson, K. K., \& Rebus, P. J. (2005). The relationship between social support and student adjustment: A longitudinal analysis. Psychology in the Schools. 42 (7), 691-706.

Dennis, J. M., Phinney, J.S., Chuatecco, L.I. (2006). The role of motivation, parental support,and peer support in the academic succes of ethnic minority frist-generation collegestudents. Journal of Collage Student Development, 46(3), 223-236.

Diener, E. (1985). Subjective well-being. Psychological Bulletin, 95(3), 42-575.

Dollete, Steese, Phillips, \& Matthews, (2004). Understanding girls' circle as an intervention on perceived social support, body image, self-efficacy, locus of control and self-esteem. The Journal of Psychology, 90 (2), $204-215$.

Edwards, S.D.(2005). A psychology of breathing methods. International Journal of Mental Health Promotion, 7 (4),28-34.

Friedlander, L.J., Reid, G.J., Shupak, N. \& Cribbie, R. (2007). Social support, self-esteem, and stress as predictors of adjustment to university among first-year undergraduates. journal of college student development, 48 (3), 259 - 275.

Gulacti, F. (2010). The effect of perceived social support on subjective well-being. Procedia Social and Behavioral Sciences. 2, 3844-3849.

Gurung, R.A.R (2006). Health Psychology: A Cultural Approach. Belmont CA: Thomson Wadsworth.

Huppert, F. A. (2009). Psychological well-being: Evidence regarding its causes and consequences. Applied Psychology: Health and Well-Being. 1, 137-164.

Karademas, E.C. (2006). Self-efficacy, social support and well-being the mediating role of optimism. Journal of personality and individual differences, 40(4), 1281-1290.

Pallant, J. (2010). SPSS survival manual: a step by step guide to data analysis using SPSS. Maidenhead :Open University Press/McGraw-Hill.

Paulhus, D. L. (1991). Measurement and control of response bias. In J.P. Robinson, P. E. Shaver, \& L.S.Wrightsman (Eds.). Measures of personality and social psychological attitudes (Vol.1, pp.1759). San Diego, CA: Academic Press.

Paulhus, D. L., \& Vazire, S. (2007). The self-report method. In R. W. Robins, R. C. Fraley, and R. Krueger (Eds.), Handbook of research methods in personality psychology (pp. 224-239). New Yor: Guilford Press.

Rawson, H.E., Bloomer, K., \& Kendall, A. (1999). Stress, anxiety, depression, and physical illness in college students. The Journal of Genetic Psychology, 155(3), 321-330.

Rufaida, H., \& Kustanti, E.R. (2017). HUBUNGAN antara dukungan sosial teman sebaya dengan penyesuaian diri pada mahasiswa rantau dari sumatera di Universitas Diponegoro. Jurnal Empati. 3 (7), 217-222. 
Ryan, A. K., Willits, F. K. (2007). Family ties, physical health, and psychological well-being. Journal of Aging Health. 19 (6), 907-920

Ryff, C. D. (1989).Happiness is everything, or is it? Explorations on the meaning of psychological well-being. Journal of Personality and Social Psychology, 57 (6), 1069-1081

Thomas, P.A. (2009). Is it better to give or to receive? social support and the well-being of older adults. The Journals of Gerontology Series B: Psychological Sciences and Social Sciences. 65 (3):351-357.

Vaux, A. (1990). An ecological approach to understanding and facilitating social support, Journal of Social and Personal Relationships 7, 507-518.

Winefield, H. R., Gill, T. K., Taylor, A. W., \& Pilkington, R. M. (2012). Psychological well-being and psychological distress: is it necessary to measure both? Psychology of Well-Being: Theory, Research and Practice. 2(1), 1-14.

Zimet, G. D., Dahlem, N. W., Zimet, S.G., and Farley, G. K. (1988). The multidimensional scale of percieved social support. Journal of Personality Assessment. 52, 30-41. 